\title{
KUŞBURNU (Rosa canina) FENOLİK BİLEŞİKLERİNİN MİKROENKAPSÜLASYONU
}

\author{
Furkan Erdem, Eda Nur Gündoğan, Merve Sılanur Yılmaz*, \\ İrem Sezgin, Yağmur Summakoğlu, Özge Şakıyan \\ Ankara Üniversitesi Gıda Mühendisliği Bölümü, Ankara, Türkiye
}

Geliş / Received: 27.02.2021; Kabul / Accepted: 02.07.2021; Online bask1 / Published online: 14.07.2021

Erdem, F., Gündoğan, E.N., Yılmaz, M.S., Sezgin, İ., Summakoğlu, Y., Şakıyan, Ö. (2021). Kuşburnu (Rosa canina) fenolik bileşiklerinin mikroenkapsülasyonu. GIDA (2021) 46 (4) 1026-1039 doi: 10.15237/gida.GD21046

Erdem, F., Gündoğan, E.N., Yılmaz, M.S., Sezgin, İ., Summakoğlu, Y., Şakıryan, Ö. (2021). Microencapsulation of rosehip (Rosa canina) phenolic compounds. GIDA (2021) 46 (4) 1026-1039 doi: 10.15237/gida.GD21046

\section{Öz}

Bu çalışmada, kuşburnu bitkisinde bulunan fenolik bileşiklerin mikroenkapsülasyonu sırasında kaplama materyali çeşidinin ve çekirdek:kaplama materyali oranının enkapsülasyon verimi ve 1 sıl stabilite üzerine etkileri incelenmiştir. Kaplama materyali olarak maltodekstrin ve gam arabik kullanılmıştır ve her iki kaplama materyali de fenolik ekstrakt tozları ile ağırlıkça 1:20 ve 1:30 oranlarında karıştırılmıştır. Mikroenkapsülasyon işlemi dondurarak kurutma yoluyla gerçekleştirilmiştir. Elde edilen mikroenkapsüller 1sıl stabilitelerinin değerlendirilmesi amacıyla kek hamuruna ilave edilerek pişirme işlemi uygulanmış ve pişirme işlemi sonundaki isıl stabiliteleri incelenmiştir. En yüksek enkapsülasyon verimi için en uygun kaplama materyalinin gam arabik, çekirdek:kaplama materyali oranının ise 1:20 olduğu belirlenmiştir. Mikroenkapsülasyon işleminin, kullanılan kaplama materyali ve çekirdek:kaplama materyali oranınından bağımsız, ssıl stabiliteyi arttırdığı tespit edilmişsir $(P<0.05)$. En yüksek 1sıl stabilite kaplama materyali olarak gam arabik, çekirdek:kaplama materyali oranı olarak da 1:30 kullanıldığında elde edilmiştir.

Anahtar kelimeler: Mikroenkapsülasyon, kuşburnu, 1sıl stabilite, verim

\section{MICROENCAPSULATION OF ROSEHIP (Rosa canina) PHENOLIC COMPOUNDS}

\begin{abstract}
In this study, the effects of coating material type and core:coating material ratio on encapsulation efficiency and thermal stability of microencapsulated phenolic compounds found in rosehip plant were investigated. Maltodextrin and gum arabic were used as coating materials and both materials were mixed with phenolic extract powders in ratios of $1: 20$ and $1: 30$ by weight. The microencapsulation process was carried out by freeze-drying. In order to evaluate the thermal stability of microencapsules, they were added to the cake dough and after baking process, their thermal
\end{abstract}

${ }^{*}$ Yazışmalardan sorumlu yazar/Corresponding author;

\merveyilmaz@ankara.edu.tr (D) (+90) $3122033300 / 3642$

国(+90) 3123178711

Furkan Erdem; ORCID no:0000-0003-3106-1525

Eda Nur Gündoğan; ORCID no:0000-00001-6005-7605

Merve Silanur YIImaz; ORCID no:0000-0002-3184-1780

İrem Sezgin; ORCID no:0000-0002-3399-3585

Yağmur Summakoğlu; ORCID no:0000-0003-2661-5436

Özge Şakıyan; ORCID no: 0000-0002-0778-8211 
stability was examined. The most suitable coating material and core:coating material ratio, which resulted in the highest encapsulation efficiency, were gum arabic and 1:20, respectively. The microencapsulation process was found to increase the thermal stability regardless of coating material and core:coating ratio $(P<0.05)$. The highest thermal stability was obtained when gum arabic was used as coating material and 1:30 was used as a core:coating material ratio.

Keywords: Microencapsulation, rosehip, thermal stability, yield

\section{GİRİ̧̧}

Rosaceae familyasinin Rosa cinsine ait olan Kuşburnu (Rosa canina L.), Türkiye'nin pek çok yöresinde rahatlikla yetişebilen yabani gül türlerinin yalanc1 meyvelerine verilen isimdir (Güler, 1997). Kuşburnu meyvesi, diğer meyvelerle karşılaştırıldığında $\mathrm{C}$ vitamini ve fenolik bileşik içeriğinin daha zengin olduğu görülmüştür (Öz vd., 2018). Yapısında bulunan askorbat, beta-karoten, tokoferol, antosiyanin ve diğer fenolik bileşikler sayesinde yüksek antioksidan aktiviteye sahiptir (Stanila vd., 2015). Dünyada yaygın kullanım alanları çay ve reçel üretimi olmakla birlikte, bebek mamasından likör üretimine kadar pek çok uygulaması söz konusu olmasına rağmen yine de kullanımı azdır (Çağlar ve Demirci, 2017). Türkiye'nin hemen her yerinde rahatlıkla yetişebilen kuşburnu meyvesinin kullanım alanı ülkemizde çay ve reçel üretiminden ileri gitmemiştir (Öz vd., 2018).

Kuşburnu meyvesine olan ilginin az olmasina karşın, yapısındaki biyoaktif bileşiklerin önemli bir bölümünü oluşturan fenolik bileşiklere olan ilgi oldukça yüksektir (Ercişli, 1996; Apak vd., 2007; Guimarães vd., 2013). Fenolik bileşiklerin antienflamatuar etkisi, antioksidan aktivitesi, antikarsinojen özelliği, antimikrobiyal ve antimutajenik etkileri, yapılan çalışmalarda rapor edilmiştir. (Orhan vd., 2007; Wenzig vd., 2008; Barros vd., 2011; Guimarães vd., 2013; Jesus vd., 2020). Farklı kuşburnu türlerinde yapilan çeşitli çalışmalarda en yüksek fenolik bileşik içeriğine Rosa canina L. serotipinde rastlanmıştır (Ercişli, 2007; Murathan vd., 2016). Kuşburnunda bulunan fenolik bileşiklerin başında floroglusinol, quercetin, gallik asit, kafeik asit gelmekte ve büyük bir kısmını apigenin oluşturmaktadır (Stanila vd., 2015; Bhave vd. 2017; Fetni vd., 2020). Bunların yanında kateşin, resveratrol ve klorojenik asit de az miktarda bulunmaktadır (Fetni vd., 2020). Fenolik bileşikler; 1şık, oksijen, nem ve sıcaklık gibi oksidasyona sebep olan çevresel etmenlere karşı oldukça dayanıksızdır (Ballesteros vd., 2017). $\mathrm{Bu}$ yüzden, enkapsülasyon işleminin uygulanması ile depolama stabilitelerinin arttırilmasi, termal dayanıklılı̆ıının geliştirilmesi ve yapının güçlendirilmesi amaçlanmaktadır.

Enkapsülasyon işlemi ile bir bileşen, başka bir madde ile kaplanarak bu maddenin içine hapsedilir. Kapsüllerin dış katmanı kaplama materyali, kaplanan materyal ise çekirdek olarak isimlendirilir (Madene vd., 2006). Fenolik bileşiklerde enkapsülasyon, çekirdek materyalin çevresel etmenlere karşı güçlendirilmesi ve reaksiyon stabilitesinin arttırilması amaciyla uygulanabildiği gibi bileşiklerin sebep olduğu ac1 tat ve kokunun maskelenmesi amaciyla da uygulanır (Desai ve Park, 2005). Kullanılacak kaplama materyalinin çekirdek ile uyumlu olması ve reaksiyona sebep olmaması önemlidir. Bu özellikleri sebebiyle maltodekstrin, gam arabik, hidrofobik modifiye nişasta ve kitozan gibi polisakkaritler s1klıkla kaplama materyali olarak tercih edilmektedir (Gouin, 2004; Madene vd., 2006; Ballestereos vd., 2017). Bunların yanı sira, meyve sularını enkapsülasyonunda maltodekstrin ve gam arabik en sik kullanilan kaplama materyalleridir (Kuck ve Noreña, 2016).

Polisakkarit ve glikoproteinlerin bir karışımı olan gam arabik; sudaki yüksek çözünürlüğü, düşük viskozitesi ve emülsiyon kapasitesinin yüksek olmas1 sebebiyle tercih edilmektedir (CanoChauca vd., 2005). Ayrıca, gam arabik içeren karışımların uzun süre 1sıl işleme maruz bırakılmasıyla proteinli bileşikler çöker ve gamın emülsiyon kabiliyeti artar (López-Franco vd., 2015). Maltodekstrin ise nişasta hidrolizi sonucu ortaya çıan ve son derece ucuz bir polisakkarittir (Tonon vd., 2009). Polisakkarit olmasına karşın organik çözücülerde çok az çözünür ve bu özelliği ve ucuz olması sebebiyle çok tercih edilir (Khoee ve Yaghoobian, 2017). 
Enkapsülasyon uygulamas1 genellikle kurutma teknikleri kullanılarak gerçekleştirilir. Püskürterek ve dondurarak kurutma, en sik kullanilan iki yöntemdir (Silva vd., 2014). Püskürterek kurutma ucuz ve geniş bir kullanım alanı sunması, işlenen ürüne zarar vermeden çalışabilmesi sebebiyle sık tercih edilir (Wen vd., 2014). Buna karşın dondurarak kurutma, vakum altında ve $-55^{\circ} \mathrm{C}$ gibi düşük sıcaklıklarda yapılması sebebiyle masraflıdır ancak suyun uzaklaştırılması düşük basınç ve sıcaklıkta gerçekleştirildiği için hücre ve yapısal bileşenler asgari düzeyde zarar görür (Gouin, 2004; Ballestereos vd., 2017). Dondurarak kurutmanın bu özelliği, fenolik bileşikler gibi hassas maddelerin enkapsülasyonunda tercih edilmesinde önemli bir nedendir (Asami vd., 2003; Wen vd., 2014; Ballesteros vd., 2017).

Bu çalışmada, kuşburnu meyvesinden elde edilen fenolik bileşiklerin maltodekstrin ve gam arabik olmak üzere iki farklı kaplama materyali kullanılarak dondurarak kurutma yöntemi ile enkapsülasyon işlemi gerçekleştirilmiştir. Farklı oranlarda kullanilan kaplama materyallerinin, fenolik bileşiklerin ssıl stabiliteleri üzerine etkisi araştırılmışır. Mikroenkapsüllerin 1sıl stabilitesinin değerlendirmesi amacıyla kapsüller, model gida olarak kullanılan kek hamurunun içine ilave edilmiş ve en uygun kaplama materyali ile uygun kaplama oranı belirlenmiştir. Böylece, içeriğindeki fenolik bileşiklerin korunması sağlanarak ilave edildiği ürünlerin fonksiyonel özelliklerinin geliştirilmesi hedeflenmiştir.

\section{Materyal ve Yöntem \\ Materyal}

Bu çalışmada kullanılan kuşburnu meyveleri (Rosa canina), Ankara'daki yerel marketlerden kuru halde temin edilmiştir. Kuru haldeki kuşburnu örnekleri, tane içindeki tüylerin uzaklaştırılmasının ardından çekirdekleriyle birlikte ögütülerek toz haline getirilmiş ve 1180 $\mu$ m'lik elekten geçirildikten sonra $+4{ }^{\circ} \mathrm{C}^{\prime} \mathrm{de}$ polietilen ambalaj içinde saklanarak depolanmıştır.

Çalısmada kullanılan gallik asit (Sigma-Aldrich), Folin-Ciocalteau reaktifi (Merck), metanol (Merck), etanol (Merck), asetik asit (Merck) ve sodyum karbonat (Merck) analitik safliktadır. Enkapsülasyon işlemi için ise gam arabik (akasya gami) (Alfasol) ve maltodekstrin (Dekstroz eşdeğeri 10-12) (Alfasol) kullanılmıştır. Kek hamuru için kullanılan tuz, kabartma tozu, süt tozu, yumurta akı tozu, kabartma tozu ve un ise Ankara'daki yerel marketlerden temin edilmiştir.

\section{Yöntem}

\section{Ekstraksiyon işlemi}

Toz haldeki kuşburnu örnekleri, ekstraksiyon işlemi için 1.25:25 (ağıllık:ağırlık (w:w)) oranında çözgen ile karıştırılmış ve çözgen olarak distile su kullanılmıştır. Örnekler, üç kademeli bir soğutma düzeneği ile desteklenmiş mikrodalga ekstraksiyon (General Electric Company, Diegem, Belçika) sistemi ile $360 \mathrm{~W}$ mikrodalga gücünde $15 \mathrm{dk}$. süre ile ekstrakte edilmiştir. Ekstraksiyon sürenin belirlenmesinde, öndenemeler sonucunda elde edilen toplam fenolik madde miktarı dikkate alınmıştır, bu değerin sabitlendiği nokta ekstraksiyon işleminin tamamlandığ nokta olarak belirlenmiştir. Mikrodalga ekstraksiyon işlemi sonunda bitki ekstraktlarının ortalama sicaklığ $82{ }^{\circ} \mathrm{C}$ olarak ölçülmüştür. Elde edilen ekstraktlar gözenek çap1 $20 \mu \mathrm{m}$ olan kaba filtre kağıdı ile filtre edilmiş, amber renkli şişelere doldurulmuş ve dondurarak kurutma işlemi için $-18^{\circ} \mathrm{C}$ 'de dondurulmuşlardır.

Dondurarak kurutma (Liyofilizasyon) işlemi Liyofilizasyon işlemi, dondurulmuş örneklerde liyofilizatörde (Taption Group Co. Ltd., Amerika) $-55^{\circ} \mathrm{C}$ 'de, $50 \mathrm{~Pa}$ vakum altında, 24 saat süresince yapılmıştır. Toz haline getirilen liyofilize örnekler amber renkli cam şişelerde enkapsülasyon işlemine kadar $+4{ }^{\circ} \mathrm{C}$ 'de depolanmıştır ve liyofilizasyon verimi $0.45 \mathrm{~g}$ kuru ekstrakt/ $100 \mathrm{~mL}$ karışım olarak hesaplanmıştır. $\mathrm{Bu}$ değer; liyofilizatör işlemi sonucu elde edilen kuru örnek miktarının başlangıçtaki sıvı ekstrakt hacmine bölünmesiyle elde edilmiştir.

\section{Mikroenkapsülasyon işlemi}

Mikroenkapsülasyon işleminde kullanılan çekirdek:kaplama materyali oranları ve kek yapımında kullanılan mikroenkapsül tozu miktarı yapılan ön denemelerle belirlenmiştir. Kaplama materyali olarak kullanilan maltodekstrin ve gam 
arabik, ağırlıkça \%10 olacak şekilde distile su ile karıştırılmıştır. Mikroenkapsülasyon işleminde $1: 20$ ve $1: 30 \quad(w / w)$ olmak üzere iki farklı çekirdek:kaplama materyali oranı kullanılmıştır. Karışımlar yüksek hızlı homojenizatörde (HG15A, Wisd, Daihan, Güney Kore) 4000 rpm'de 5 dakika süreyle homojenize edilmiş, ardından $35 \mathrm{~W}$ ultrasonik güçte 20 dakika süresince ultrasonikasyona (Sonoplus Ultrasonic Homogenizer, HD 2070, Almanya) maruz bırakılmıştır. Elde edilen karışımlar $-18{ }^{\circ} \mathrm{C}$ 'de dondurulduktan sonra $-55^{\circ} \mathrm{C}$ 'de ve $50 \mathrm{~Pa}$ vakum altında 24 saat süresince liyofilizatörde (Taption Group Co. Ltd., Amerika) kurutulmuştur. Kurutulup toz haline getirilmiş örnekler 1180 $\mu$ m'lik elekten geçirildikten sonra analizlerde kullanılıncaya kadar amber renkli cam şişelerde $18{ }^{\circ} \mathrm{C}$ 'de depolanmıştır. Enkapsülasyon verimliliği, mikroenkapsüllerin toplam fenolik madde miktarı, yüzey fenolik madde miktarı ve 1sıl stabilite sonuçları, kullanılan kaplama materyalleri ve kaplama oranına göre değerlendirilmisstir.

\section{Model gida denemeleri}

Mikroenkapsülasyon uygulamaları sonras1 mikroenkapsüllerin ve enkapsüle edilmemiş kuşburnu eksraktı tozunun 1sıl stabilitelerinin karşılaştırılması için kek örnekleri kullanılmışır. Çalışmada kullanılan kek formülasyonu, Alifakı (2019) tarafindan sunulan formülasyonun düzenlenmiş bir halidir. Kek hamurunun formülasyonunda fenolik bileşenlere olan negatif etkisi nedeniyle şeker kullanılmamıştır (Waterhouse, 2002). Kek hamuru için 100 gram buğday unu kullanılmıştır. Kek karışımı un bazında $\% 25$ yağ, \%12 yağsız süt tozu, $\% 9$ yumurta beyaz1 tozu, $\% 3$ tuz, $\% 5$ kabartma tozu ile $140 \mathrm{~mL}$ su kullanılarak hazırlanmıştır. Kek hamuru hazırlanırken öncelikle eritilen yağ içerisine $9 \mathrm{~g}$ yumurta beyazı ilave edilmiş ve karışım bir dakika süre ile karıştırılmıştır. $100 \mathrm{~g}$ una sirası ile $12 \mathrm{~g}$ yağsız süt tozu, $3 \mathrm{~g}$ tuz ve $5 \mathrm{~g}$ kabartma tozu karıştırıldıktan sonra yağlı karışımla birleştirilerek 3 dakika süre ile karıştırılmıştır. 100 g kek hamurunun içine 100 mg enkapsüle edilmemiş ekstrakt tozu veya $100 \mathrm{mg}$ mikro enkapsül tozu ilave edilerek 1 dakika daha karıştırılmış ve elde edilen hamur 35 dakika süreyle $175^{\circ} \mathrm{C}$ 'de pişirilmiştir (Arçelik, MF $35 \mathrm{~B}$,
Türkiye). Pişirme işleminde firına 100'er g olacak şekilde iki adet kek örneği yerleştirilmiştir. Kontrol grubu olarak ise enkapsüle edilmemiş ekstrakt tozu ve mikroenkapsül tozu içermeyen örnekler hazırlanmıştır. Kekler üç tekerrürlü olarak hazırlanmıştır.

\section{Analizler \\ Fenolik bileşik miktarı tayini için örnek hazırlama}

Yüzey fenolik bileşik miktarı analizi için, $100 \mathrm{mg}$ örnek, 50:50 etanol:metanol (hacim:hacim (v:v)) solüsyonu içerisinde disperse edilmiş, 1 dakika boyunca vortekslenmiş (DAIHAN Scientific Co., Ltd., Korea) ve daha sonra $0.45 \mu$ m'lik filtreden geçirilmiştir. Toplam fenolik madde tayini için ise $100 \mathrm{mg}$ örnek, hacimce 50:8:42'lik etanol:asetik asit:su (v:v:v) çözeltisi ile birlikte vorteks karıştırıcıda (Daihan, VM10, Wisd Laboratory Instruments, Güney Kore) 1 dakika karıştırıldıktan sonra $0.45 \mu$ m'lik filtreden geçirilmiştir.

\section{Fenolik bileşik miktarı analizi}

Yüzey fenolik bileşik miktarının ve toplam fenolik bileşik miktarının analizi Folin-Ciocalteu metotu kullanılarak yapılmıştır (Singleton ve Rossi, 1965). Toplam fenolik madde değerleri gallik asit eşdeğeri (GAE)/g kuru madde olarak belirtilmiştir. Filtreden geçirilen örnekler, distile su kullanilarak 26 kat seyreltilmiştir. $0.1 \mathrm{~mL}$ seyreltik örnek, $0.9 \mathrm{~mL}$ distile su ve $4 \mathrm{~mL} 0.2 \mathrm{~N}$ Folin-Ciocalteau reaktifi eklenmiş ve 2 dakika sonra $5 \mathrm{~mL} \% 7.5$ 'lik $\mathrm{NaCO}_{3}$ çözeltisi eklenmiştir. 2 saat karanlıkta ve oda sicaklığında bekletilen örneklerin UV-VIS spektrofotometrede (Lambda35, Perkin Elmer, ABD) 765 nm dalga boyunda absorbans değerleri ölçülmüştür.

Gallik asit standart eğrisi için öncelikle $0.5 \mathrm{~g} / 100$ $\mathrm{mL}$ olacak şekilde stok çözeltisi hazırlanmıştır. Hazırlanan stok çözeltisinden 0-0.5-1.0-1.5-2-2.5$5 \mathrm{~mL}$ alınarak 50 mL'lik balon jojelere yerleştirilmiş, hacimler distile su ile tamamlanarak derişimleri sirasiyla 0-50-100-150-200-250-500 $\mathrm{mg} / \mathrm{L}$ olan gallik asit çözeltileri hazırlanmıştır. Çözeltilerin absorbansları UV-VIS spektrofotometrede (Lambda35, Perkin Elmer, ABD) $765 \mathrm{~nm}$ dalga boyunda ölçülerek standart 
eğri çizilmiştir. Çizilen standart eğriye ait formül $\mathrm{y}=0.0014 \mathrm{x}-0.0076$ olarak, $\mathrm{R}^{2}$ değeri ise 0.9976 olarak belirlenmiştir.

\section{Enkapsülasyon verimi}

Enkapsülasyon verimi eşitlik (1) ile hesaplanmıştır (Çilek vd., 2012):

$\% E E=\frac{E P C}{T P C} \times 100$

Eşitlikte EE; enkapsülasyon verimini (\%), EPC: Toplam fenolik bileşik miktarı ve yüzey fenolik bileşik miktarının farkını (mg gallik asit/g kuru madde) ve TPC: toplam fenolik bileşik miktarını (mg gallik asit/g kuru madde) temsil etmektedir. Enkapsülasyon verimliliği için kullanılan Eşitlik 1 'de pay ve paydada kaplama materyalinin miktarı aynı anda etkili olduğundan nihai sonucu etkilemediği görülmüss, bu nedenle hesaplamada dikkate alınmamıştır.

\section{Is1l stabilite}

Isıl stabilitenin hesaplanmasında eşitlik (2) kullanılmıştır:

$\%$ Kayıp $=$ $\underline{\text { Hamurdaki toplam fenolik bileşik miktarı-Kekteki toplam fenolik bileșik miktarı }} \times$ Hamurdaki toplam fenolik bileșik miktarı

100

Formülasyondan kaynaklanabilecek değerleri elimine edebilmek için kontrol kek hazırlanmış ve pişirilmiş ve kontrole ait değerler çıkarılarak enkapsül ve tozdan kaynaklanan fenolik bileşik miktarları kullanılmıştır (Luca vd., 2014).

\section{İstatistiksel analiz}

Analizler sonucu elde edilen veriler Minitab 17 istatistik paket programı kullanılarak istatistiksel olarak değerlendirilmiştir. Tek yönlü varyans analizi ile (ANOVA) grup ortalamaları arasindaki farklar belirlenmiştir ve istatistiksel açıdan önemli bulunan değerler Tukey testi ile $P \leq 0.05$ önem derecesine göre verilmiştir.

\section{Sonuçlar ve tartışma}

\section{Yüzey fenolik bileşik miktarı}

Farklı kaplama materyalleri ve kaplama oranları kullanılarak mikroenkapsülasyon işlemi uygulanmış kuşburnu örneklerinin yüzey fenolik bileşik miktarları Şekil 1'de verilmiştir. Analiz sonucunda yüzey fenolik bileşik miktarları gam arabik ile 1:20 ve 1:30 oranlarında kaplanan örnekler için sirasiyla $1.32 \pm 0.21$ ve $2.19 \pm 0.17$; maltodekstrin ile $1: 20$ ve $1: 30$ oranlarında kaplanan örnekler içinse sirasiyla $2.24 \pm 0.12$, $1.35 \pm 0.19 \mathrm{mg}$ GAE/g kuru madde olarak bulunmuştur. Kapsül yüzeyinde fazla miktarda fenolik bileşik bulunması, işlemin düşük verimle gerçekleştiğini ve etkin bir kaplama sağlanamadığını göstermektedir. Gam arabik ile kaplanmış örneklerde kaplama maddesi oranı arttırldıkça yüzey fenolik bileşik miktarının arttı̆̆1 görülmüştür $(P<0.05)$. Bu bilgiden yola çıkılarak gam arabik miktarının artmasıyla enkapsülasyon etkinliğinin azaldığı söylenebilir. Maltodekstrin ile kaplanmış örneklerde ise kaplama maddesi oranı arttıkça yüzey fenolik bileşik miktarının azaldığı görülmüş ve bu azalma istatistiki açıdan önemli bulunmuştur $(P<0.05)$. Bu durum maltodekstrin miktarının artmasıyla enkapsülasyon etkinliğinin artması şeklinde açıklanabileceği gibi başlangiç fenolik madde konsantrasyonundaki düşüşle de ilişkilendirilmiştir. Çilek vd. (2012) tarafindan vişne posasındaki fenolik bileşiklerin enkapsülasyonu üzerine farklı oranlarda gam arabik ve maltodekstrin kullanılarak gerçekleştirilen çalışmada da benzer sonuçlar elde edilmiştir. Maltodekstrin oran1 1:10'dan 1:20'ye çıkartıldığında yüzey fenolik miktarı $14 \mathrm{mg}$ GAE/g kuru maddeden 4.24 mg GAE/g kuru maddeye düşmüştür.

Benzer bir durum Saikia vd. (2015) tarafindan Averrhoa carambola posasındaki fenolik bileşiklerin maltodekstrin ile ekstraksiyonu üzerine yapılan çalışmada da görülmektedir. Maltodekstrin oranının artmasıyla yüzey fenolik miktarı önemli ölçüde azalmış, 1:10 oranından 1:20 oranına geçişte $129 \mathrm{mg}$ GAE/100 g kuru maddeden 23 mg GAE/100 g kuru maddeye düşmüştür.

\section{Toplam fenolik bileşik miktarı}

Mikroenkapsüllerin toplam fenolik madde miktarlarının kaplama maddesi çeşidi ve oranına göre değişimleri Şekil 2'de sunulmuştur. Elde edilen veriler incelendiğinde kaplama maddesi ve oranının, mikroenkapsüllerdeki toplam fenolik bileşik miktarına etkisinin istatistiki açıdan önemli 
olduğu görülmüştür $(P<0.05)$. Kullanılan gam arabik ve maltodekstrin miktarı arttıkça toplam fenolik madde miktarında azalma görülmüştür. Bu durum, kaplama materyali miktarındaki artışın, fenolik madde konsantrasyonunda azalışa neden olması ile ilişkilendirilmiş ve bu nedenle enkapsülasyon verimi açısından bir yorum yapılamamıştır. Ancak literatürde benzer sonuçları rapor eden pek çok çalışma yer almaktadır. Tomsone vd. (2020) bayır turpu suyunun, aralarında maltodekstrinin de bulunduğu kaplama materyalleri kullanılarak mikroenkapsülasyonu üzerine bir çalışma yayınlamışlardır. Yapılan çalışmada 20:80, 50:50 ve 80:20 oranlarında maltodekstrin kullanılarak çekirdek:kaplama materyali oranları denenmiş ve kaplama materyali miktarındaki artışın toplam fenolik bileşik miktarını $6129 \pm 15 \mathrm{mg} \mathrm{GAE} / 100$ $\mathrm{g}$ kuru maddeden $1915 \pm 26 \mathrm{mg}$ GAE /100 g kuru maddeye kadar düşürdüğü rapor edilmiştir. Kaplama materyallerinin karışımdaki konsantrasyonlarındaki artışın toplam fenolik bileşik miktarına olumsuz etki yapması kaçınılmazdır. Başka bir ifade ile, toplam fenolik bileşik miktarındaki bu azalış, karışımlar oluşturulurken fenolik bileşik bakımından zengin olan kuşburnu tozunun toplam kuru madde içindeki oranının azalmasından kaynaklandığ1 söylenebilir. Bunun yanında enkapsülasyon işlemi aşamalarından homejenizasyon işleminin de fenolik bileşiklerde mekanik hasara neden olabileceği literatürde rapor edilmiştir (Alifak1, 2019). Ayrıca, mikroenkapsülasyon işlemi için kullanılan dondurarak kurutma sirasinda fenolik bileşik kaybı, dondurma işlemi ve gıda üzerinde oluşan 1031ehidrasyona stresi ile ilisskilendirilebilir (Papoutsis, 2018). Liyofilizasyon işlemi sonras1 gerçekleştirilen parçalama işlemi de bu kayıptan sorumlu tutulmaktadır. Parçalama işlemi sırasında oksijene maruz kalan materyal yüzeyinin artışı fenolik bileşiklerin oksidasyonuna neden olarak kaybına sebebiyet verdiği literatürde farklı yayınlarda rapor edilmiştir (Papoutsis vd., 2018; Baysan vd., 2021). Bu sebeplere ek olarak dondurarak kurutma işlemi sırasında meyve dokularında bulunan bazı enzimlerin serbest kalması sonucunda fenolik bileşiklere zarar verebileceği de bildirilmiştir (Shofian vd., 2011). Ancak bu çalışma kapsamında örneklerin liyofilizasyon ile enkapsülasyonu öncesi gerçekleştirilen mikrodalga ekstraksiyonunun gerçekleştirildiği sıcaklık ve süre dikkate alındığında inaktive olmayan enzim etkisinin diğer sebeplere göre daha sınırlı düzeyde olduğu düşünülmektedir.

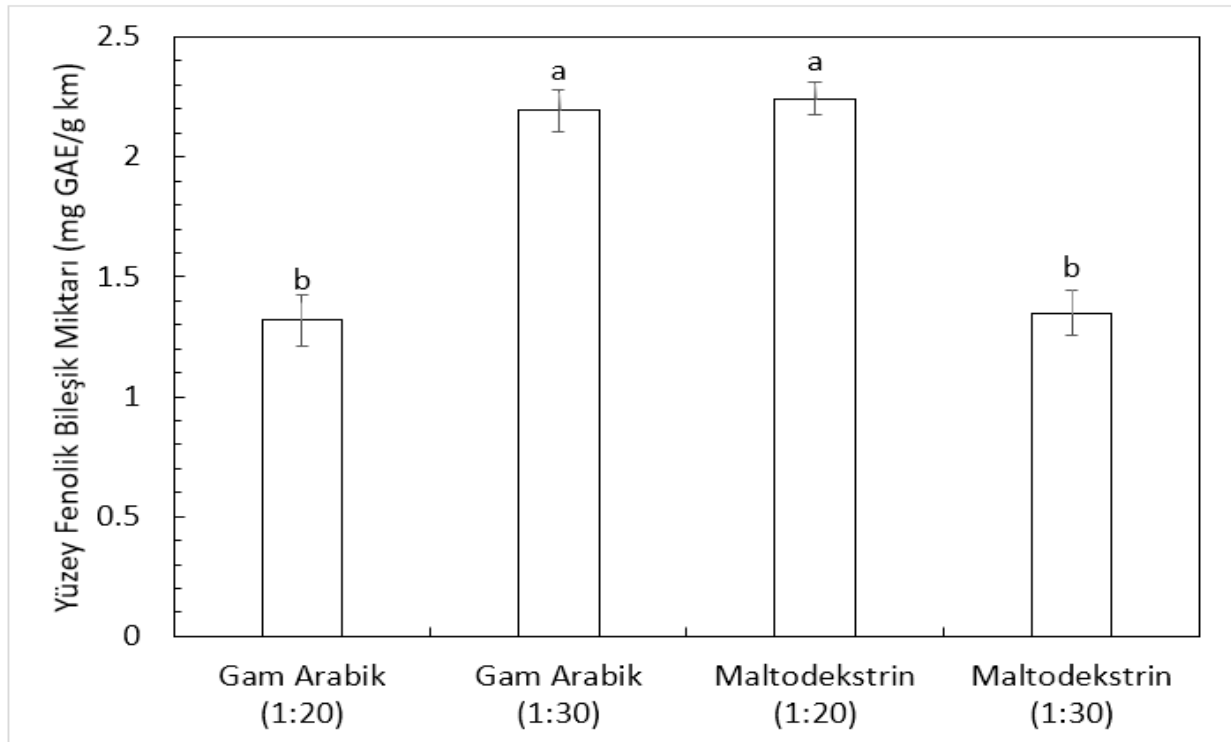

Şekil 1. Farklı kaplama materyalleri ve çekirdek:kaplama materyali oranları ile hazırlanan mikroenkapsüllerin yüzey fenolik bileşik miktarları

Figure 1. Surface phenolics of encapsulated powders with different coating materials and core: coating material ratios 


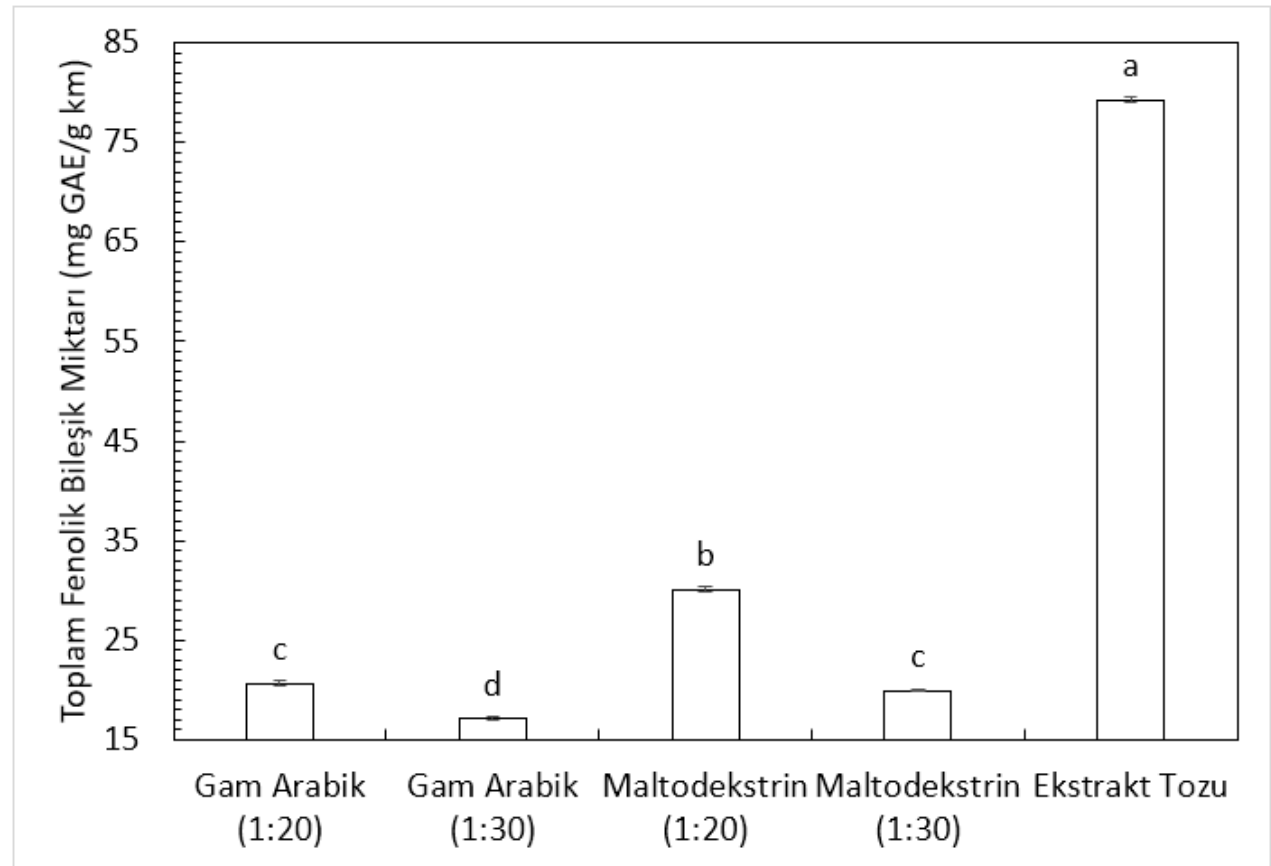

Şekil 2. Enkapsüle edilmemiş ekstrakt tozunun ve farklı kaplama materyalleri ve çekirdek:kaplama materyali oranları ile hazırlanan mikroenkapsüllerin toplam fenolik bileşik miktarları

Figure 2. Total phenolic contents of extract powder and encapsulated powders with different coating materials and core: coating material ratios

Kullanilan farklı kaplama materyalleri karşılaştırıldığında maltodekstrin ile kaplanan örneklerin toplam fenolik bileşik miktarının gam arabikle kaplananlara kıyasla daha yüksek olduğu tespit edilmiştir. Bu durum, maltodekstrinin daha yüksek çözünürlük ve daha düşük viskozite değerlerine (Sarabandi vd. 2019) sahip olmasi nedeniyle fenolik bileşikleri daha iyi sarması ile açıklanabilmektedir. Sarabandi vd. (2019) tarafindan gerçekleştirilen patlıcan kabuğu ekstraktlarının mikroenkapsülasyonu ile ilgili başka bir çalısmada da maltodekstrin ile kaplanmış örneklerde, gam arabik ile kaplanmış örneklere kiyasla daha yüksek oranda toplam fenolik madde görüldüğü bildirilmiştir. Benzeri şekilde Tolun vd. (2016) üzüm polifenollerinin enkapsülasyonu üzerine yaptıkları çalışmada maltodekstrinin fenolikleri daha iyi sarması nedeniyle daha yüksek toplam fenolik bileşik değerleri elde ettiklerini raporlamışladır.

$\mathrm{Bu}$ çalş̧mada kuşburnu fenoliklerinin 1:20 oranında maltodekstrin kaplama materyali ile kaplanarak elde edilen mikroenkapsüllerinin toplam fenolik bileşik miktarı diğer ürünlerin maltodekstrin kullanılarak 1:20 oranında hazırlanmış mikroenkapsülleri ile karşılaştırıldığında Averrboa carambola'dan (2.3 mg GAE/g kuru madde (Saikia vd. 2015)), brokoli yan ürünlerinden $(3.50 \mathrm{mg}$ GAE/g kuru madde (Marinelli vd. 2020)) ve gilaburundan (12.67 mg GAE/g kuru madde (Alifak1, 2019)) daha yüksek ancak soğan kabuğundan (209.24 mg GAE/g kuru madde (Akdeniz, 2017)) ve üzüm çekirdeğinden (657.86 mg GAE/g kuru madde (Yadav vd., 2020)) daha düşük olduğu görülmüsstür.

\section{Enkapsülasyon verimi}

Farklı kaplama maddeleri ve kaplama oranlarının enkapsülasyon verimine etkisi Şekil 3'te sunulmuştur. En yüksek enkapsülasyon verimi $(\% 94.19 \pm 0.16)$ kaplama materyali olarak gam arabiğin, çekirdek:kaplama materyali oranı olarak ise 1:20 oranının kullanıldığı örneklerde elde edilmiştir. Gam arabikle kaplanan örneklerde çekirdek:kaplama materyali oranının artmasının enkapsülasyon verimliliğini önemli ölçüde azalttı̆̆1 görülmüsstür $(P<0.05)$. Maltodekstrin kullanılarak yapılan enkapsülasyon işleminde ise 
çekirdek:kaplama materyali oranın artmasıyla azalan enkapsülasyon verimliği istatistiksel açıdan önemli bulunmamıştır $(P>0.05)$. Benzeri şekilde, Akdeniz vd. (2017) tarafindan soğan kabuğundaki fenolik bileşiklerin enkapsülasyonu ile ilgili sunulan çalş̧mada maltodekstrin kaplama oranı 1:10'dan 1:20'ye çıkarıldığında enkapsülasyon verimin istatistiki olarak önemli derecede değişmediği belirtilmiştir. Yine aynı çalışmada gam arabik ve maltodekstrin karışımı ile hazırlanan mikroenkapsüllerde ise gam arabiğin, enkapsülasyon verimliliğini azalttı̆̆1 rapor edilmiştir. Sarabandi vd. (2019) tarafından yapılmış patlıcan kabuğu ekstraktlarının enkapsülasyonu ile ilgili başka bir çalışmada da maltodekstrin ve gam arabik kaplama materyali olarak değerlendirilmiş, daha yüksek çözünürlük ve daha düşük viskozite değerlerine sahip maltodekstrinle kaplanmış örneklerin enkapsülasyon verimliliğinin daha yüksek olduğu gösterilmiştir. Karbonhidrat bazlı bir kaplama materyali olan maltodekstrin ve gam yapıdaki gam arabik'in karşılaştırıldığı diğer bir çalışmada yine maltodekstrinin üzüm polifenollerini kaplamada daha yüksek verim sergilediği bu durumun maltodekstrinin fiziksel özellikleri nedeniyle fenolikleri daha iyi sarmalamasıyla ilişkili olduğu bildirilmiştir (Tolun vd. 2016).

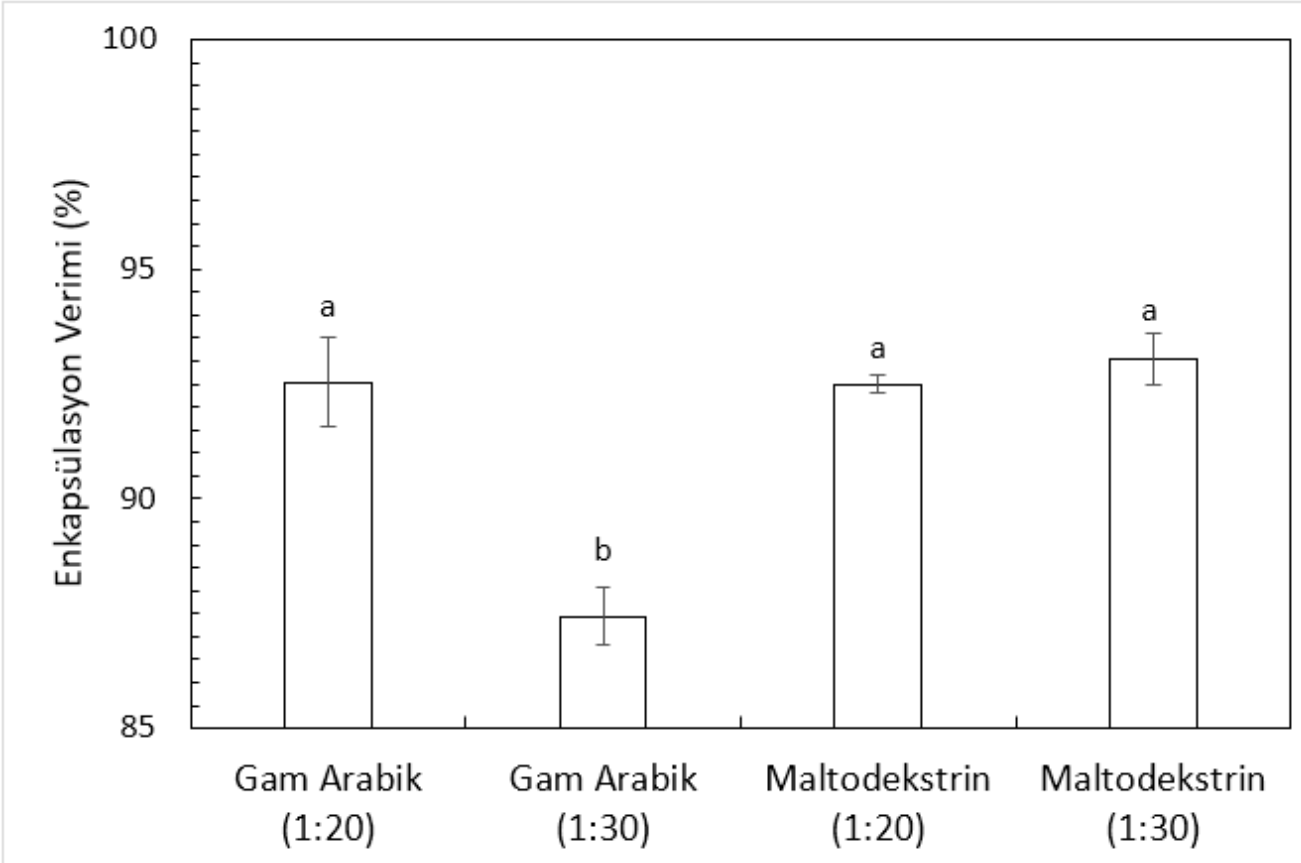

Şekil 3. Farklı kaplama materyallerinin ve çekirdek:kaplama materyali oranlarının enkapsülasyon verimine etkisi.

Figure 3. The effect of different coating materials and core: coating material ratios on encapsulation efficiency

\section{Is1l stabilite}

Farklı kaplama materyalleri ve kaplama oranları kullanılarak hazırlanmış mikroenkapsüllerin ve enkapsüle edilmemiş ekstrakt tozunun kek hamuruna eklendikten sonraki toplam fenolik bileşik miktarları Şekil 4'te verilmiştir. Mikroenkapsüller ve enkapsüle edilmemiş ekstrakt tozu, kek hamurunun hazırlanmasinin ardından hamura eklenerek karıştırılmıştır. Kaplama materyali olarak gam arabik ya da maltodekstrin kullanılması mikroenkapsül eklenmiş hamur örneklerinin toplam fenolik madde miktarı üzerinde istatistiksel olarak önemli bir fark oluşturmuştur $(P<0.05)$. Gam arabikle kaplanmış mikroenkapsüllerin eklendiği hamurların toplam fenolik bileşik miktarlarının maltodekstrinle kaplanan mikroenkapsüllerin eklendiklerine göre daha düşük olduğu bulunmuştur. Kaplama oranının etkisi incelendiğinde ise her iki kaplama materyali için de oranda artışın hamur örneklerinin toplam fenolik bileşik miktarı üzerine etkili olmadığı 
tespit edilmiştir $(P>0.05)$. Enkapsüle edilmemiş ekstrakt tozu eklenen hamur örnekleri, maltodekstrin ile kaplanmış mikroenkapsül eklenen örneklerle karşılaştırıldığında toplam fenolik bileşik miktarının daha düşük bulunması karıştırma ve çırpma sırasında enkapsüle edilmemiş ekstrakt tozlarının daha çok hasar görmesiyle ilişkilendirilmiştir. Buna ek olarak, enkapsülasyon işlemi sırasında uygulanan homojenizasyon işleminin de fenolik bileşiklere zarar verdiği literatürde bildirilmiştir (Alifaki 2019).

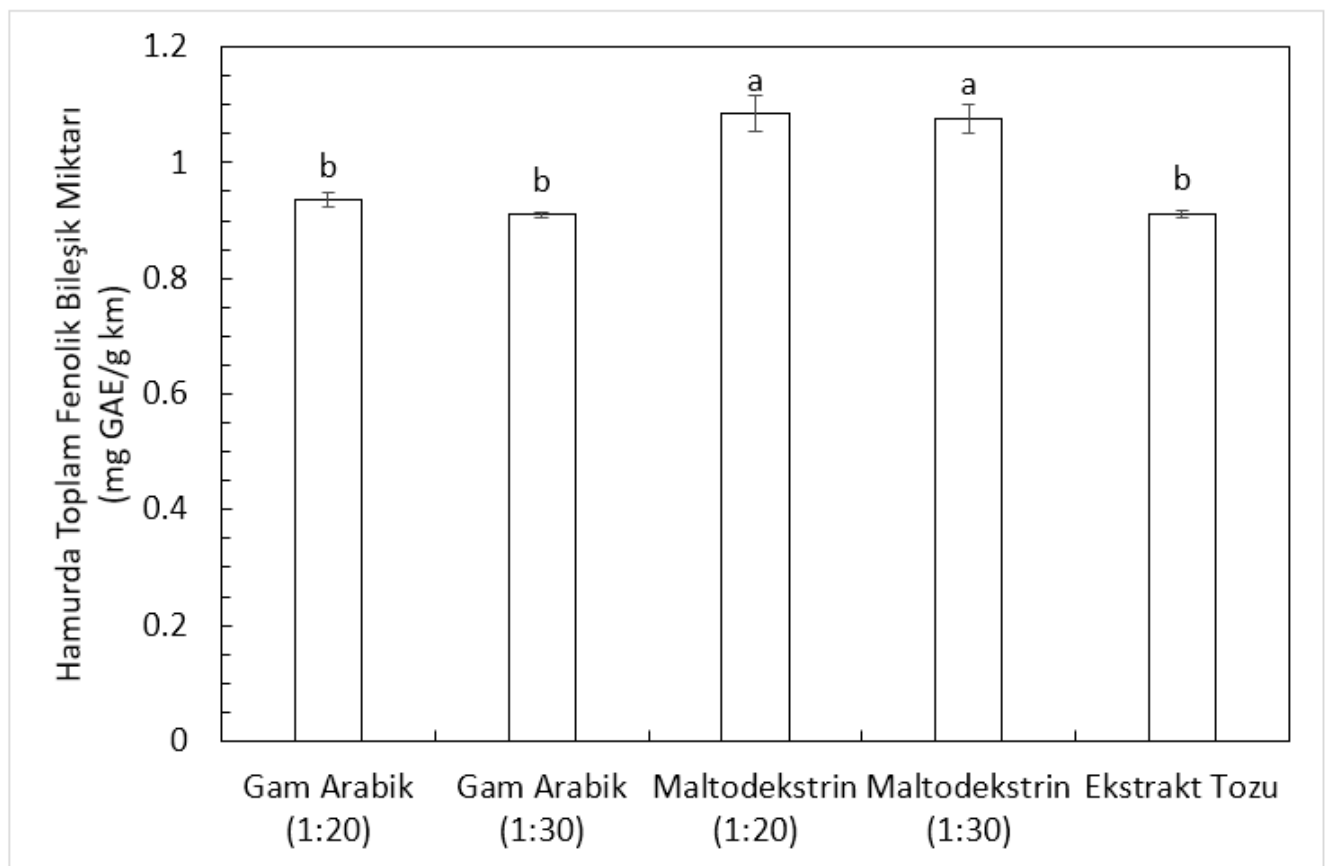

Şekil 4. Farklı kaplama materyalleri ve kaplama oranları ile hazırlanmış mikroenkapsüllerin ve enkapsüle edilmemiş ekstrakt tozunun eklendiği kek hamurlarının toplam fenolik bileşik miktarları

Figure 4. Total phenolic content of extract powder and microcapsules with different coating materials and coating ratios added cake batter

Farklı kaplama materyali ve kaplama oranları kullanılarak hazırlanan mikroenkapsüllerin eklendiği hamurların pişirilmesi sonucu elde edilen kek örneklerinin toplam fenolik madde miktarları Şekil 5'te verilmiştir. Gam Arabik mikroenkapsüllerinin ilave edildiği kek örneklerinde kaplama oranının toplam fenolik madde miktarına etkisi istatistiksel olarak önemli bulunmuştur $(P<0.05)$. 1:30 kaplama oranına sahip olan numunedeki toplam fenolik madde miktarının daha yüksek olduğu belirlenmiştir. Literatürde yapılan çalışmalarda maltodekstrin mikroenkapsüllerinin işlem koşullarının etkisi ile kısmen parçalandiğ1, gam arabik mikroenkapsüllerinin ise küresel yüzey yapısı sayesinde daha dayanıklı olduğu bildirilmiştir (Krishnan vd., 2005). Maltodekstrin mikroenkapsüllerinin ilave edildiği kek örneklerinde ise kaplama oranının fenolik bileșik miktarı üzerine istatistiksel açıdan önemli bir etkisinin olmadığ1 görülmüştür $\left(\begin{array}{ll}P & <0.05\end{array}\right)$. Kaderides vd. (2020) tarafindan gerçekleştirilen, portakal kabuğu yan ürünlerinin nar kabuğu ekstraktının enkapsülasyonu için kullanıldığı bir çalışmada ise, mikroenkapsüller ve enkapsüle edilmemiş ekstraktlar kurabiyelerde biyofonksiyonel bileșenler olarak kullanılmıștır. $210^{\circ} \mathrm{C}$ 'de 10 dakika süreyle gerçekleștirilmiș olan pişirme ve sonrasındaki saklama işlemi sırasında fenolik madde içeriği incelenmiş, mikroenkapsül eklenmiş örneklerde \%65 ve mikroenkapsüle edilmemiş ekstrakt eklenmiş örneklerde ise $\% 76$ kayıp olduğu belirtilmiştir. Elde edilen sonuçlar doğrultusunda mikroenkapsülasyon işleminin fenolik bileşik içeriğindeki kaybı azalttığı tespit edilmiştir. 


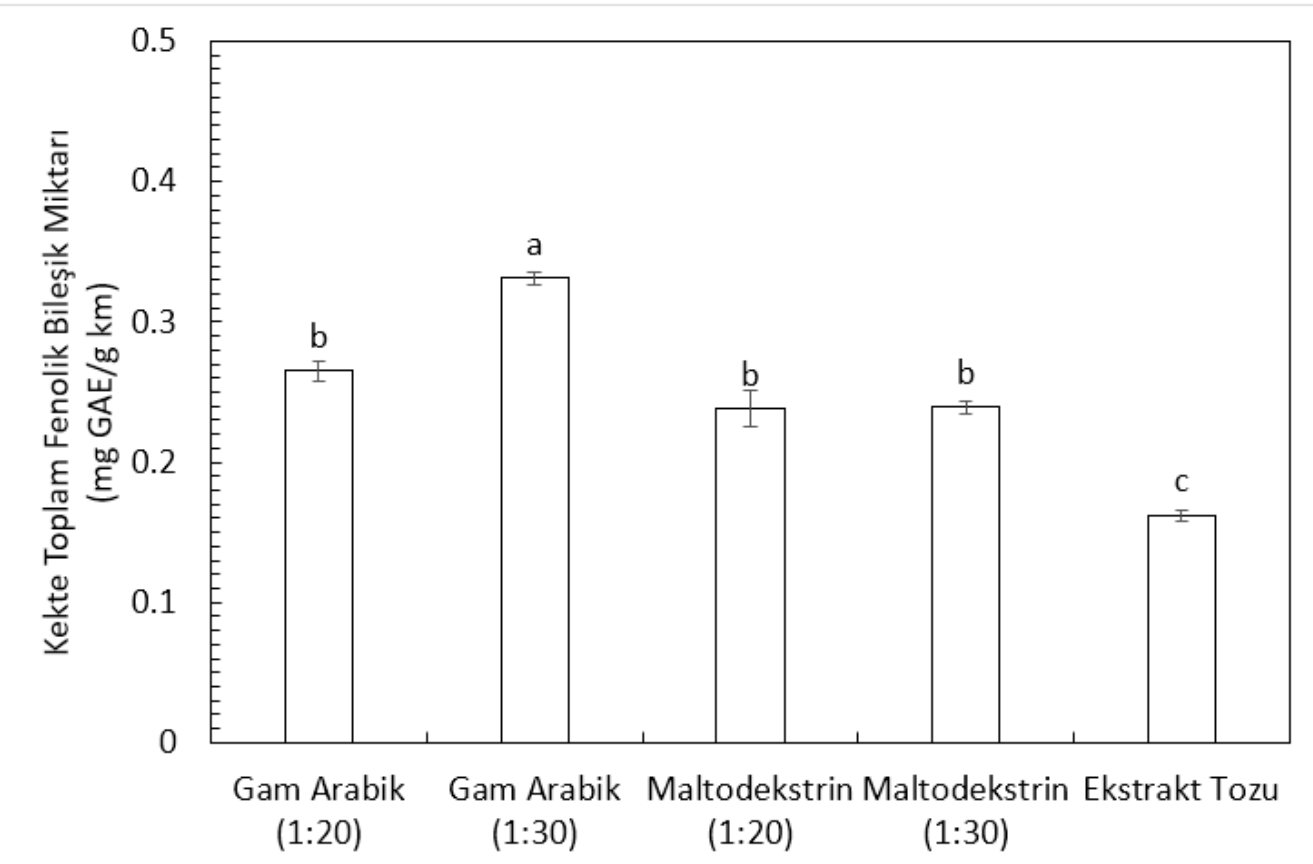

Şekil 5. Farklı kaplama materyali ve kaplama oranları ile hazırlanan mikroenkapsül ve enkapsüle edilmemiş ekstrakt tozu eklenen keklerin pişirme sonundaki toplam fenolik bileşik miktarları

Figure 5. Total phenolic contents of extract powder and microcapsules with different coating materials and coating ratios added cakes after baking

Farklı kaplama materyalleri ve kaplama oranları kullanılarak hazırlanan mikroenkapsüllerin ve enkapsüle edilmemiş ekstrakt tozunun isil stabiliteleri ise Şekil 6'da verilmiştir. Enkapsülasyon işleminin pişirme sırasında toplam fenolik bileşik miktarının korunmasına etkisi istatistiksel açıdan önemli bulunmuştur $(P<0.05)$. Bir başka deyişle, mikroenkapsülasyon işleminin fenolik bileşiklerin ısıl işlem koşullarının etkisiyle zarar görmesini engellediği tespit edilmiştir. Maltodekstrin mikroenkapsülleri için kaplama oranları arasında 1sıl stabilite açısından istatistiksel olarak önemli bir fark görülmezken $(P>0.05)$ gam arabik mikroenkapsüllerinde kaplama oranının 1sil stabiliteyi arttırdığ bulunmuştur $(P<0.05)$. 1:30 çekirdek:kaplama materyali oranı ile kaplanmış mikroenkapsüllerin 1sıl stabilitesinin en yüksek olduğu tespit edilmiştir. Elde edilen bu veriler ışı̆̆ında, 1sıl stabilite açısından (\%37.51 1 1.32) en ideal kaplama materyalinin gam arabik ve en uygun çekirdek:kaplama materyali oranının ise 1:30 olduğu sonucuna varılmıştır. Literatürde de benzeri sonuçlar rapor edilmiştir; Suhag vd. (2016) kaplama materyali olarak \%35-40-45 oranlarında gam arabik kullanılan bal tozu mikroenkapsüllerini incelemişler ve gam arabik oranındaki artışın örneklerde $C$ vitamininin 1sıl stabilitesini arttırdığını bildirmiş̧lerdir. Ballesteros vd. (2017) tarafindan yapılan bir başka çalışmada atık kahve çekirdeği ekstraktlarının enkapsülasyonu araştırılmış ve enkapsülasyonun fenolik bileşiklerin 1sıl stabilitesini arttırdığ ve gam arabiğin daha verimli olduğu belirtilmiştir. Gong vd. (2020) ise yaptıkları çalışmada tarçın aromasının 1sıl stabilitesini arttırmak için ultrasonik destekli mikroenkapsülasyon işlemi uygulamış ve mikroenkapsülasyon işlemi ile aromanın $150-250^{\circ} \mathrm{C}$ pişirme sicaklıklarında bile korunduğunu bildirmişlerdir. Luca vd. (2014) ise maltodekstrin ve gam arabik karışımı kullanarak gerçekleştirdikleri enkapsülasyon işleminin, vişneden elde edilmiş olan fenolik bileşiklerin $175^{\circ} \mathrm{C}$ 'de 22 dakika gerçekleştirilen uygulamada 1s1l stabilitesini \%22.2'den \%30.7'ye yükselttiğini belirtmişlerdir. 


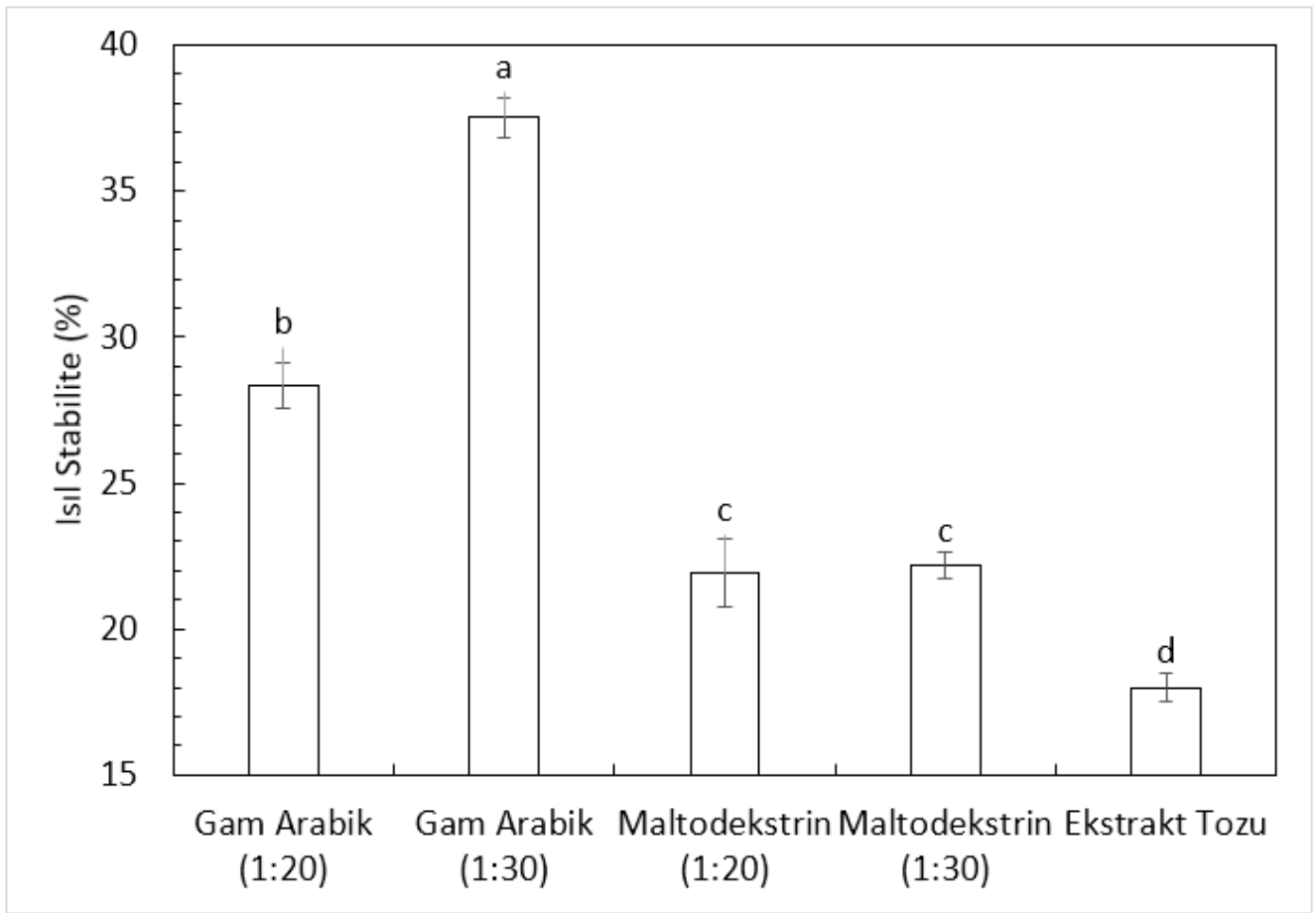

Şekil 6. Farklı kaplama materyalleri ve kaplama oranları ile hazırlanan mikroenkapsüllerin ve enkapsüle edilmemiş kuşburnu ekstraktı tozunun 1sıl stabiliteleri

Figure 6. Thermal stability of extract powder and microcapsules with different coating materials and coating ratios and rosehip extract

Kuşburnu fenolik bileșiklerinin ișlem koșullanına karș1 stabilitelerini arttırmak için mikroenkapsülasyon işleminin uygulanması ve uygun kaplama materyali ve kaplama oranlarının $(1: 20$ ve $1: 30)$ incelenmesi sonucu elde edilen verilerin literatüre katk1 sağladığ1 düşünülmektedir. Enkapsülasyon verimi ve 1sil stabilite bir arada değerlendirildiğinde en uygun kaplama materyalinin gam arabik, en uygun çekirdek:kaplama materyali oranının ise 1:30 olduğu sonucuna varılmıştır. Bu şartlar altında hazırlanan mikroenkapsüllerde en yüksek enkapsülasyon verimi $\% 94.19 \pm 0.16$, 1sıl stabilite değeri ise \%37.51 \pm 1.32 olarak hesaplanmıştır. Bundan sonra yapilacak çalışmalarda, belirlenen en uygun işlem koşulları ve kaplama materyali ile hazırlanan mikroenkapsüllerin daha detaylı incelenmesinin, parçacık özelliklerinin, morfolojik yapilarının, saklama stabilitelerinin ve biyoyararlılıklarının belirlenmesinin uygun olacağı düşünülmektedir.

\section{ÇIKAR ÇATIŞMASI BEYANI}

Yazarların başka kişiler ve/veya kurumlar ile çıkar çatışması bulunmamaktadır.

\section{YAZAR KATKILARI}

FE, ENG, MSY, İS ve YS deneylerin planlanmas1 ile yapilışında görev almışlar ve taslak metni oluşturmuşlardır. OS danışman olarak çalışma fikrinin oluşmasında, deney tasarımının oluşturulmasında, verilerin değerlendirilmesinde ve taslağın kontrolünde/düzenlenmesinde görev almıştır. Yazarlar makalenin son halini okumuş ve onaylamıştır.

\section{TEŞEKKÜR}

Çalışmalarımızın tüm aşamalarında öneri ve bilgilerini paylaşarak çalışmalarımızın yönlenmesine katkıda bulunan Yaşar Özlem ALIFAKI'ya en içten teşekkürlerimizi bir borç biliriz. 
Bu bitirme tezi KUŞBURNU BİTKISİNDEN ELDE EDILEN FENOLIK BILEŞİKLERIN MİKROENKAPSÜLASYONU' başliklı, 20Ö0443001 proje numaralı Ankara Üniversitesi Bilimsel Araştırma Projeleri Müdürlügü̈nce desteklenen proje kapsamında yürütülmüsstür.

\section{KAYNAKÇA}

Alifakı, Ö.Y. (2019). Gilaburu (Viburnum opulus L.) meyvesinden yeni yöntemlerle fenolik bileşenlerin ekstraksiyonu ve gilaburu tozunun mikroenkapsülasyonu. Ankara Üniversitesi Fen Bilimleri Enstitüsü Gıda Mühendisliği Anabilim Dalı Doktora Tezi, Ankara, Türkiye, 274 s.

Akdeniz, B. (2017). Evaluation of different coating materials for encapsulation of phenolic compounds extracted from onion (Allium cepa) skin. Orta Doğu Teknik Üniversitesi Fen Bilimleri Enstitüsü G1da Mühendisliği Anabilim Dalı Yüksek Lisans Tezi, Ankara, Türkiye, 131 s.

Akdeniz, B., Şumnu, G., Şahin, S. (2017). The effects of maltodextrin and gum arabic on encapsulation of onion skin phenolic compounds. Chem Eng Trans, 57: 1891-1896, doi: 10.3303/CET1757316.

Asami, D.K., Hong, Y.J., Barrett, D.B., Mitchell, A.E. (2003). Comparison of the total phenolic and ascorbic acid Content of freeze-dried and airdried marionberry, strawberry, and corn grown using conventional, organic, and sustainable agricultural practices. J Agric Food Chem, 51(5): 1237-1241, doi: 10.1021/jf020635c.

Ballesteros, L.F., Ramirez, M.J., Orrego, C.E., Teixeira, J.A., Mussatto, S.I. (2017). Encapsulation of antioxidant phenolic compounds extracted from spent coffee grounds by freeze-drying and spray-drying using different coating materials. Food Chem, 237: 623-631, doi: 10.1016/j.foodchem.2017.05.142.

Barros, L., Carvalho, A.M., Ferreira, I.C.F.R. (2011). Exotic fruits as a source of important phytochemicals: Improving the traditional use of Rosa canina fruits in Portugal. Food Res Int, 44(7): 2233-2236, doi: 10.1016/j.foodres.2010.10.005.

Baysan, U., Bastıŏglu, A.Z., Coşkun, N.Ö., Takma, D.K., Balçık, E.Ü., Hilal, S.N., Koç, M.
(2021). The effect of coating material combination and encapsulation method on propolis powder properties. Powder Technol, 384: 332-341, doi: 10.1016/j.powtec.2021.02.018.

Bhave, A., Schulzova, V., Chmelarova, H., Mrnka, L., Hajslova, J. (2017). Assessment of rosehips based on the content of their biologically active compounds. J Food Drug Anal, 25(3): 681-690, doi: 10.1016/j.jfda.2016.12.019.

Cano-Chauca, M., Stringheta, P.C., Ramos, A.M., Cal-Vidal, J. (2005). Effect of the carriers on the microstructure of mango powder obtained by spray drying and its functional characterization. Innovative Food Sci and Emerg Technol, 6(4): 420-428, doi: 10.1016/j.ifset.2005.05.003.

Çağlar, M.Y., Demirci, M. (2017). Üzümsü meyvelerde bulunan fenolik bileşikler ve beslenmedeki önemi. Avrupa Bilim ve Teknoloji Dergisi, 7(11): 18-26.

Çilek, B., Luca, A., Hasirci, V., Şahin, S., Şümnü, G. (2012). Microencapsulation of phenolic compounds extracted from sour cherry pomace: effect of formulation, ultrasonication time and core to coating ratio. Eur Food Res Technol, 235(4): 587-596, doi: 10.1007/s00217-012-1786-8.

Desai, K.G.H., Park, H.J. (2005). Recent developments in microencapsulation of food ingredients. Drying Technol, 23(7): 1361-1394, doi: 10.1081/DRT-200063478.

Ercişli, S. (1996). Gümüşhane ve ilçelerinde doğal olarak yetişen kuşburnuların (Rosa spp.) seleksiyon yoluyla ıslahı ve çelikle çoğaltma imkanları üzerinde bir araştırma. Atatürk Üniversitesi Fen Bilimleri Enstitüsü Bahçe Bitkileri Anabilim Dalı, Doktora Tezi, Erzurum, Türkiye, $174 \mathrm{~s}$.

Ercişli, S. (2007). Chemical composition of fruits in some rose (Rosa spp.) species. Food Chem, 104(4): 1379-1384, doi: 10.1016/j.foodchem.2007.01.053.

Fetni, S., Bertella, N., Ouahab, A., Zapater, J.M.M., Fernandez, S.P.T. (2020). Composition and biological activity of the Algerian plant Rosa canina L. by HPLC-UV-MS. Arabian J Chem, 13(1): 1105-1119, doi: 10.1016/j.arabjc.2017.09.013. 
Gong, C., Lee, M.C., Godec, M., Zhang, Z., Abbaspourrad, A. (2020). Ultrasonic encapsulation of cinnamon flavor to impart heat stability for baking applications. Food Hydrocoll, 99: 105316, doi: 10.1016/j.foodhyd.2019.105316.

Gouin, S. (2004). Microencapsulation: Industrial appraisal of existing technologies and trends. Trends in Food Sci Technol, 15(7-8): 330-347, doi: 10.1016/j.tifs.2003.10.005.

Guimarães, R., Barros, L., Calhelha, R.C., Carvalho, A.M., Queiroz, M.J.R.P., Ferreira, I.C.F.R. (2013). Bioactivity of different enriched phenolic extracts of wild fruits from northeastern portugal: A comparative study. Plant Foods Hum Nutr, 69(1): 37-42, doi: 10.1007/s11130-0130394-5.

Güler, S. (1997). Doğu Anadolu Bölgesi'nde doğal yaylliş gösteren kuşburnu (Rosa L.) türleri, yetiştirme teknikleri ve kullanım alanları. Doğu Anadolu Ormancilık Araştırma Müdürlüğü Yayınlanı, Teknik Rapor Serisi No. 2, Erzurum, Türkiye, $59 \mathrm{~s}$.

Kaderides, K., Mourtzinos, I., Ghoula, A.M. (2020). Stability of pomegranate peel polyphenols encapsulated in orange juice industry by-product and their incorporation in cookies. Food Chem, 310: 125849, 10.1016/j.foodchem.2019.125849.

Khoee, S., Yaghoobian, M. (2017). Niosomes: a novel approach in modern drug delivery systems. Nanostructures for Drug Delivery, 207-237, doi: 10.1016/B978-0-323-46143-6.00006-3.

Krishnan, S., Bhosale, R., Singhal, R.S. (2005). Microencapsulation of cardamom oleoresin: Evaluation of blends of gum arabic, maltodextrin and a modified starch as wall materials. Carbohydr Polym, 61(1): $\quad 95-102, \quad$ doi: 10.1016/j.carbpol.2005.02.020.

Kuck, L.S., Noreña, C.P.Z. (2016). Microencapsulation of grape (Vitis labrusca var. Bordo) skin phenolicextract using gum Arabic, polydextrose, and partially hydrolyzed guar gum as encapsulating agents. Food Chem, 194: 569-576, doi: 10.1016/j.foodchem.2015.08.066.

López-Franco Y.L., Gooycolea F.M., LizardiMendoza, J. (2015). Gum of Prosopis Acacia species. Polysaccharides, 1-20, doi: 10.1007/978-3319-03751-6_14-1.

Luca, A., Çilek, B., Hasırc1, V., Şahin, S., Şumnu, G. (2014). Storage and baking stability of encapsulated sour cherry phenolic compounds prepared from micro- and nano-suspensions. Food Bioprocess Technol, 7(1): 204-211, doi: 10.1007/s11947-013-1048-1.

Madene, A., Jacquot, M., Scher, J., Desobry, S. (2006). Flavour encapsulation and controlled release - a review. Int J Food Sci Technol, 41(1): 121, doi: 10.1111/j.1365-2621.2005.00980.x.

Marinelli, V., Spinelli, S., Angiolillo, L. Nobile, M.A.D., Conte, A. (2020). Emerging techniques applied to by-products for food fortification. $J$ Food Sci Tecbnol, 57: 905-914, doi: 10.1007/s13197-019-04123-8.

Murathan, Z.T., Zarifikhosroshahi, M., Kafkas, E., Sevindik, E. (2016). Characterization of bioactive compounds in rosehip species from east anatolia region of Turkey. Ital J Food Sci, 28(2): 314-325.

Orhan, D.D., Harvetioğlu, A., Küpeli, E., Yeşilada, E. (2007). In vivo anti-inflammatory and antinociceptive activity of the crude extract and fractions from Rosa canina L. fruits. J Ethnopharmacol, 112(2): 394-400, doi: 10.1016/j.jep.2007.03.029.

Öz, M., Baltac1, C., Deniz, İ. (2018). Gümüşhane yöresi kuşburnu (Rosa canina L.) ve siyah kuşburnu (Rosa pimpinellifolia L.) meyvelerinin C vitamini ve şeker analizleri. Gümüşhane Üniversitesi Fen Bilimleri Enstitüsü Dergisi, 8(2): 284-292, doi: 10.17714/gumusfenbil.327635.

Papoutsis K., Golding, J.B., Vuong, Q., Pristijono, P., Stathopoulos, C.E., Scarlett, C.J., Bowyer, M. (2018). Encapsulation of citrus byproduct extracts by spray-drying and freezedrying using combinations of maltodextrin with soybean protein and t-carrageenan. Foods, 7(7): 115-127, doi: 10.3390/foods7070115.

Saikia, S., Mahnot, N.K., Mahanta, C.L. (2015). Optimisation of phenolic extraction from Averrboa carambola pomace by response surface methodology and its microencapsulation by spray 
and freeze drying. Food Chem, 171: 144-152, doi: 10.1016/j.foodchem.2014.08.064.

Sarabandi, K., Jafari, S.M., Mahoonak, A.S., Mohammadi, A. (2019). Application of gum arabic and maltodextrin for encapsulation of eggplant peel extract as a natural antioxidant and color source. Int J Biol Macromol, 140: 59-68, doi: 10.1016/j.ijbiomac.2019.08.133.

Shofian, N.M., Hamid, A.A., Osman, A., Saari, N., Anwar, F., Dek, M.S.P., Hairuddin, M.R. (2011). Effect of freeze-drying on the antioxidant compounds and antioxidant activity of selected tropical fruits. Int J Mol Sci, 12(7), 4678-4692, doi: 10.3390/ijms12074678.

Silva, P.T.D., Fries, L.L.M., Menezes, C.R.D., Holkem, A.T., Schwan, C.L., Wigmann, É.F., Bastos, J.O., Silva, C.B. (2014). Microencapsulation: concepts, mechanisms, methods and some applications in food technology. Ciênc. Rural, 44(7): 1304-1311, doi: 10.1590/0103-8478cr20130971.

Stanila, A, Diaconeasa, Z., Roman I., Sima, N., Maniutiu, D., Roman, A., Sima, R. (2015). Extraction and characterization of phenolic compounds from rose hip (Rosa canina L.) using liquid chromatography coupled with electrospray ionization - mass spectrometry. Not Bot Horti Agrobo, 43(2): 349-354, doi: $10.15835 /$ nbha43210028.

Suhag, Y., Nayik, G.A., Nanda, V. (2016). Effect of gum arabic concentration and inlet temperature during spray drying on physical and antioxidant properties of honey powder. J Food Meas Charact, 10(2): 350-356, doi: 10.1007/s11694-016-9313-4.

Tolun, A., Altıntaş, Z., Artık, N. (2015). Microencapsulation of grape polyphenols using maltodextrin and gum arabic as two alternative coating materials: development and characterization. J Biotechnol, 239: 23-33, doi: 10.1016/j.jbiotec.2016.10.001.

Tomsone, L., Galoburda, R., Kruma, Z., Durrieu, V., Cinkmanis, I. (2020). Microencapsulation of Horseradish (Armoracia rusticana L.) Juice using spray-drying. Foods, 21(9): 1332-1349, doi: 10.3390/foods 9091332 .

Tonon, R.V., Brabet, C., Pallet, D., Brat, P., Hubinger, M.D. (2009). Physicochemical and morphological characterisation of açai (Euterpe oleraceae Mart.) powder produced with different carrier agents. Int J Food Sci Technol, 44(10): 19501958, doi: 10.1111/j.1365-2621.2009.02012.x.

Waterhouse, A.L. (2002). Determination of total phenolics. Curr Protoc Food Anal Chem. 6(1): I1.1.1I1.1.8.

Wen, J., Chen, G., Alany, R.G. (2014). Theories and concepts of nano-materials, nano- and microencapsulation. Nano Microencapsul Foods. 1542, doi: 10.1002/9781118292327.ch2.

Wenzig, E.M., Widowitz, U., Kunert, O., Chrubasik, S., Bucar, F., Knauder E., Bauer, R. (2008). Phytochemical composition and in vitro pharmacological activity of two rose hip (Rosa canina L.) preparations. Phytomedicine, 15(10): 826835, doi: 10.1016/j.phymed.2008.06.012.

Yadav, K., Bajaj, R.K., Mandal, S., Mann, B. (2020). Encapsulation of grape seed extract phenolics using whey protein concentrate, maltodextrin and gum arabica blends. J Food Sci Technol, 57: 426-434, doi: 10.1007/s13197-01904070-4. 